Павлунько М. Я., канд. військ. наук

(0000-0001-8255-6245)

Посмітюх О. І., канд. військ. наук, доцент

$(0000-0002-4467-9532)$

Міроненко П. О., канд. техн. наук, доцент

(0000-0001-6388-1763)

Інститут забезпечення військ (сил) та інформаційних технологій Національного університету оборони України імені Івана Черняховського, Київ

\title{
Загрози національній безпеці у військовій сфері України на короткострокову та середньострокову перспективу
}

Резюме. У статті розглянуто основний чинник, що впливає на розвиток ситуації довкола України та становить основну загрозу їі національній безпеці у військовій сфері. Визначено, що Російська Федерація, незважаючи на певне зниження інтенсивності бойових дій на Донбасі, готова до військового вторгнення в Україну, зокрема у вигляді повномасштабної наступальної операції. Російська Федерація у рамках “гібридної” війни проти України активізувала практику політичного тероризму, що свідчить про ії неспроможність дестабілізувати обстановку на українській території організацією масових соціальних заворушень.

Ключові слова: “гібридна” війна; загроза; ситуація; прогноз; безпека.

Постановка проблеми. 32014 року і у найближчій перспективі загрозу національній безпеці України переважно становить агресивна політика Російської Федерації (РФ) у політичній, економічній, інформаційній та військовій сферах. Протягом останніх років керівництво РФ, незважаючи на зовнішній тиск, проводить активну політику щодо встановлення російського контролю над пострадянським простором i намагається повернути Україну до сфери свого впливу, оскільки це для РФ є принципово в рамках реалізації ії політики.

Крім цього з 1991 року, після розпаду Радянського Союзу, уряди сусідніх країн, а саме Румунії, Угорщини, Польщі під впливом місцевих засобів масової інформації (3МI), тиском політичних, радикально налаштованих, партій почали висувати до України територіальні претензії, як приклад здійснювати “приховану експансію" завдяки видачі урядом Румунії та Угорщини закордонних паспортів громадянам прикордонних районів, навчання в середньоосвітніх школах угорською мовою, що також становить загрозу національній безпеці та інтересам України тощо.

Отже, аналіз перспективних загроз національній безпеці у військовій сфері України від РФ, особливо під час “гібридної” війни $з$ Україною, на Південно-Західному стратегічному напрямку, а також стосунків 3 європейськими країнами на заході України, на сьогодні залишаються актуальними.
Огляд останніх досліджень i публікацій. Нині у Воєнній доктрині Росії [1], яка була прийнята в грудні 2014 року та доопрацьована, на основі положень нової Стратегії національної безпеки РФ [2] від 2015 року трактується зовнішня політика Росії стосовно пострадянських країн, зокрема i України. Відносини України з європейськими країнами висвітлено у публікаціях:

[3] - проаналізовано завдання бойового застосування ЗС РФ на основних стратегічних (операційних) напрямках;

[4] - проведено аналіз характеру “гібридних" воєн як продовження імперської політики РФ стосовно України, інших країн і міжнародних організацій;

[5] - здійснено аналіз воєннополітичних наслідків розвитку ситуації довкола України;

[6] - проаналізовано розвиток ситуації довкола України та у світі на найближчу i середньострокову перспективу;

[7] - висвітлені основні тенденції у розвитку ситуації довкола України;

[8-12] - здійснено аналіз стосунків сусідніх держав 3 Україною щодо спірних територій та їх напрями дій у зовнішній сфері.

Мета статті. На основі аналізу доктринальних документів 3 національної безпеки Російської Федерації, а також висловлювань державних і політичних діячів держав, які мають сумісний кордон 3 Україною (Румунія, Молдова, Угорщина, Польща) визначити основні загрози національній безпеці у військовій сфері України, перспективи розвитку воєннополітичної обстановки довкола неї. 
На основі визначених загроз проаналізувати особливості реалізації стратегії і тактики, сусідніх держав та їх напрями дій у зовнішній сфері щодо посягання на територіальну цілісність України.

Виклад основного матеріалу дослідження. Окупація Криму під виглядом підтримки “зеленими чоловічками” проведення демократичного референдуму щодо приєднання його до РФ, дії РФ на території Донецької та Луганської областей, ведення “гібридної” війни, є головним викликом національній безпеці у військовій сфері та територіальній цілісності України на сьогодні. Дії Російської Федерації системні за характером і $є$ складовою частиною політики режиму президента РФ. Так, протягом останніх років перехід РФ до проведення активної політики зі встановленням російського контролю над пострадянським простором призвели до внесення коректив до Воєнної доктрини РФ на основі положень нової Стратегії національної безпеки.

"Гібридна" війна є одним із методів проведення зовнішньої політики РФ через збройні сили як одного 3 інструментів реалізації іiі імперської політики. Завдання збройних сил РФ визначено в іiі Стратегії національної безпеки та Воєнній доктрині [1-3].

Під час проведення “гібридноі” війни можливий перехід до проведення наступальної операції проти України (у разі виникнення сприятливих умов) - під виглядом дій “ополченців" або під приводом захисту російських громадян та російськомовного населення. Розглядаються такі варіанти:

проведення обмеженої наступальної операції 3 району збройного конфлікту на сході України для оточення та захоплення м. Маріуполь, а також створення вихідних позицій для подальшого розгортання наступу у західному напрямку;

проведення повномасштабної наступальної операції для створення коридору до Криму та Придністров'я, а в разі успіху окупації східних і південних регіонів України [3].

Характер “гібридних" воєн у сучасній геополітичній ситуації не є оригінальним. Так до подібних методів вдавались вже протягом багатьох тисячоліть. Концепція, яка визначена китайським ідеологом військового мистецтва Сунь-Цзи в його трактатах, визначала що “спочатку необхідно зруйнувати замислене противником, потім розбити його альянси, а вже після цього знищити його військо" [4]. Для досягнення такої мети в стародавньому Китаї часто вдавалися до підкупу впливових осіб з ворожого табору, що і заклало основи політичної корупції. Зазначений підхід став інструментом зовнішньої політики сучасної РФ.

3 початком активних процесів дезінтеграції СРСР методи “гібридної” війни РФ активно застосовувала проти України, намагаючись залучити іï до сфери свого впливу. Такі дії особливо активізувалися починаючи 32012 року. По суті, 3 цього моменту Росія розв'язала повномасштабну “гібридну” війну проти України.

РФ, реалізуючи свою політику, зважає на певні особливості, що виникають у ситуації 3 Україною, а також на іiі зовнішню i внутрішню політику. У зв'язку з цим в [4] виділено два основні етапи, а саме: до і після початку збройної агресії РФ проти України в лютому 2014 року.

На периому emani, на початку 2000-х років, РФ істотно активізувала свій вплив на Україну застосовуючи методи "гібридної" війни: підкуп; залучення в корупційні схеми; впровадження агентів; ослаблення силових структур; посилення присутності; нав'язування ідей; підтримка рухів; русифікація України, зокрема, застосовуються методи підкупу українських політиків, створюється проросійське лобі в Україні, послаблюються українські силові структури, вноситься розкол в українське суспільство, надається підтримка проросійським та іншим антиукраїнським силам.

Другий етап реалізації стратегії РФ після початку збройної агресії в лютому 2014 року. На цьому етапі РФ використовує такі методи “гібридної” війни проти України: дискредитація; зосередження надпотужних угруповань; вторгнення до Криму; дезінтеграція; використання “загонів ополченців” (НЗФ), фактично - підрозділів російських спецслужб і військ спеціального призначення, найманців та місцевих кримінальних угруповань.

Методи "гібридної" війни РФ активно застосовує i для реалізації своїх неоімперських інтересів щодо інших країн та міжнародних організацій, насамперед США, держав-членів НАТО, СС. Напрями зусиль РФ щодо досягнення своїх стратегічних цілей у цій сфері такі [4]:

нав'язування ідеї 3 відновлення сфер впливу у світі з передаванням пострадянських 
територій (включно з Україною) під контроль РФ;

підрив єдності держав-членів НАТО, СС та посилення розбіжностей між США i Свропою щодо політики санкцій проти РФ;

ослаблення держав-членів СС через провокування нестабільності та внутрішніх конфліктів у європейських країнах;

виправдання російської політики щодо України та залучення США, НАТО і ЄС до їі реалізації;

переконання держав-членів $\mathrm{CC}$ i міжнародні організації в припиненні підтримки України, зокрема в питаннях іiі європейської та євроатлантичної інтеграції;

провокування протиріччя між Україною i США, державами-членами НАТО і $\mathrm{CC}$, країнами Центрально-Східної Свропи.

Серед основних методів “гібридних" дій РФ 3 досягнення зазначених цілей слід навести такі:

формування проросійського лобі в керівництві i політико-бізнесових колах західних країн за допомогою підкупу політиків i бізнесменів, зокрема у спосіб надання хабарів, фінансування їх передвиборних компаній, а також залучення до російського бізнесу;

втручання у президентські i парламентські вибори в західних країнах для впливу на результати, зважаючи на російські інтереси;

дестабілізація обстановки в державахчленах НАТО і СС через європейські сили проросійського, лівого, євроскептичного, націоналістичного напряму;

політична гра на політико-економічних і економічних інтересах європейського і американського бізнесу в РФ.

Після невдалої спроби РФ забезпечити подібними методами для себе вигідних результатів, держава перейшла до прямих провокацій. Зокрема, втрутившись у внутрішній конфлікт у Сирії, РФ спричинила “міграційну” кризу в Свропі.

32014 року РФ продовжує вживати заходів із підтримання перманентної напруженості в зоні конфлікту на сході України, надавати допомогу самопроголошеним республікам “ДНР" i "ЛНР" та зберігати свою військову присутність на їх території. Крім того, тиск на Україну у політичній, економічній та інформаційній сферах супроводжується заходами 3 дестабілізації обстановки на українській території та провокуванням політичної кризи в країні [5].
Зокрема, у військовій сфері проявами такої політики РФ стали систематичні збройні провокації на Донбасі, із періодичними загостреннями, насамперед у районах міст Донецьк (Авдіївка), Луганськ та Маріуполь та на Світлодарській дузі. На сьогодні РФ готова до активніших дій, включно 3 проведенням повномасштабного наступу вглиб території України (у т. ч. для створення сухопутного коридору до Криму та Придністров’я) [5].

3 початком "гібридної" війни на сході України США і низка країн Свропи ввели економічні санкції проти Росіі. Проте керівництво РФ, незважаючи на зовнішній тиск, і надалі у короткостроковій перспективі становитиме загрозу у політичній, економічній, інформаційній та військовій сферах. РФ і надалі намагатиметься повернути Україну до сфери свого впливу, оскільки це принципово в рамках реалізації неоімперської політики. Підтвердженням цієї політики $\epsilon$ прагнення Росії відпрацювати варіант формального повернення самопроголошених республік (“ЛНР”, “ДНР”) до складу України, але під своїм фактичним контролем. До того ж Росія залишатиме свої війська на території "ЛНР" і “ДНР" та за необхідності матиме змогу використати їх для розширення масштабів воєнного вторгнення в Україну.

Розв'язати донбаську проблему Росія обіцяла лише після того, як Україна погодиться 3 чинністю "формули Штаймайєра".

Під час переговорів лідерів “нормандської” четвірки Україна погодилася на певні поступки Росії. За їх підсумками у грудні 2019 року ухвалено рішення стосовно: подальшого обміну полоненими; закріплення режиму припинення вогню; розведення військ на низці нових ланок лініі фронту; розширення повноважень Спеціальної моніторингової місії ОБСЕ; подальшої реалізації Мінських домовленостей, зокрема створення умов для проведення виборів на окупованих територіях українського Донбасу.

Також залишилася нерозв'язана проблема Криму: Росія категорично відмовилася обговорювати кримське питання, оголошуючи його “повністю закритим”. На цьому фоні продовжуються заходи 3 його мілітаризації. Станом на кінець 2019 року загальну кількість російських військовослужбовців на півострові було доведено до 31,5 тис. осіб. Загалом угруповання ЗС РФ в окупованому Криму включає 40 танків, до 580 одиниць броньованої техніки, до 160 важких 
артилерійських установок, 122 бойові літаки, 62 вертольоти, 34 кораблі та 7 підводних човнів [6].

За таких обставин США, НАТО та СС не припинили надавати допомогу Україні у іï протистоянні з Росією. Так партнери України систематично порушували питання російської анексії Криму та окупації Донбасу під час різноманітних міжнародних заходів та перемовин 3 представниками РФ. Крім того було продовжено антиросійські санкції, а також програму 3 надання фінансової допомоги Україні на проведення реформ, на підтримку економіки та зміцнення оборонної сфери.

Узагалі, на боці України залишилась Організація Об'єднаних Націй. Так, 14 листопада 2019 року Третій комітет Генеральної асамблеї ООН ухвалив проєкт резолюції про захист прав людини в Криму в умовах російської окупації, а 9 грудня Генеральна асамблея $\mathrm{OOH}$ ухвалила резолюцію "Проблема мілітаризації Автономної Республіки Крим та міста Севастополя (Україна), а також частин Чорного та Азовського морів".

Однак економічні проблеми РФ через західні санкції, складну внутрішню ситуацію та активну діяльність опозиції можливо відчутно уповільнюватимуть реалізацію таких планів стосовно України [6].

За такої ситуації Україна залишається на тій позиції, де перетинаються інтереси Заходу і РФ та, по суті, постає одним із вирішальних чинників впливу на подальші події у світі. Таким чином, від того, як вирішуватиметься українське питання, i залежатиме те, чи вдасться США зупинити експансію РФ і не допустити досягнення нею рівня колишнього СРСР, або вона все ж таки постає новим центром сили світового рівня. Саме цим i визначається політика Заходу 3 підтримки України [7].

Проте не всі країни Заходу мають загальний політичний вектор щодо підтримки України.

Так, у 2007 році, глава Румунії Траян Бесєску, під час виступу перед Свропарламентом, посилаючись на пакт Молотова-Ріббентропа, заявив, що зробить все від нього залежне, щоб “повернути в Європу молдаван”, з якими у румун загальна історія, культура, традиції. Також під час зустрічі із студентами університету “Нижній Дунай” у місті Галац він заявив, що "румуни 3 обох берегів Пруту (тобто румуни і молдавани) не будуть довгий час розділені та об'єднаються в рамках ЄC”. "Після того як Молдавія увійде до $\mathrm{EC}$, залишиться тільки намальований кордон, а Ріббентроп і Молотов встануть із могил від обурення, що накресленні ними кордони уже не існують", - зазначив глава Румуніі.

Молдавське питання пропонувалось вирішити введенням до складу Молдови частини Чернівецької (Північна Буковина) та Одеської (Південна Бессарабия) областей України [8].

Так, на початку 2009 року територіальний спор між Україною та Румунією переріс у міжнародний конфлікт, який розглядався на рівні Єврокомісії. Як результат, Україна в Міжнародному суді ОOH програла Румунії острів Зміїний, який за рішенням суду перестав значитись прибережною лінією України. Унаслідок цього Бухарест отримав майже 80 \% спірної території [8].

$\begin{array}{cccc}\text { У зв'язку } & \text { 3 подіями в } \begin{array}{c}\text { Україні в } \\ \text { румунському }\end{array} \text { суспільстві } & \text { розродився }\end{array}$ психологічний фантом минулого - серйозно обговорюється ідея повернути “історично румунські”, але несправедливо втрачені в XIX i XX віках території, які тепер є Західною Україною. Місцеві ЗМІ закликали керівництво країни готуватись до військової інтервенції в Україну для захисту "румунських територій” Північної Буковини, Південної Бессарабії. Так, румунська газета "Adevarul" поставила запитання правлячій еліті країни: "Україна находиться на порозі громадянської війни. Зовсім не виключене розділення країни на проєвропейський Захід і проросійський Схід. Чи готова Румунія втрутитись для захисту румун Північної Буковини і Південної Бессарабіi” [9].

Екс-кандидат у президенти Польщі Гжегож Браун зробив заяву під час відкриття XV Міжнародного Катинського мотопробігу, що Польща без “кресів" (Західна Білорусь та Західна Україна) - не держава у повному сенсі. "Польща після втрати "кресів" це як людина після ампутації або лоботомії. Я кажу “так назване прикордоння”, оскільки це землі наших батьків та наших предків”, - повідомив Браун [11].

Також у ЗМІ з'являлась інформація від одного із депутатів польського Сейму про те, що глава Угорщини Віктор Орбан після 2014 року пропонував Польщі поділити Україну за зонами впливу. Фактично окупувати. Спростовування цієї інформації не було. Необхідно врахувати активні інвестиції Угорщини в Закарпатську область, а також 
масову видачу угорських паспортів, що може мати в майбутньому велику загрозу для України. Однак на офіційному рівні Угорщина заперечує такі плани. $€$ необхідність не забувати, що у свій час депутат Держдуми РФ Володимир Жириновський пропонував країнам-сусідам України (Польщі, Угорщині) iii поділити, що $\epsilon$ як мінімум одним підтвердженням загрози для України. Правда тоді він офіційної відповіді не отримав [12].

Висновок. Отже, беззаперечним $є$ той факт, що ситуація довкола України $є$ нестабільною, основну загрозу національній безпеці у військовій сфері становить агресивна політика РФ у політичній, економічній, інформаційній та військовій сферах. Як результат, залишається ймовірна збройна агресія РФ, яка, незважаючи на певне зниження інтенсивності бойових дій на Донбасі, готова до військового вторгнення в Україну, зокрема у вигляді повномасштабної наступальної операції.

Одними 3 причин вторгнення $з$ більшою вірогідністю буде спроба розв'язання конфлікту в Донецькій та Луганській областях збройним шляхом (імовірні дії РФ проведення миротворчої операції із захисту прав і свобод російськомовного населення).

Уряди країн, що межують з Україною, під впливом місцевих 3МІ та тиском політичних, радикально налаштованих партій, висувають претензіі, на території, "несправедливо" втрачені у XIX та XX століттях, які тепер є Західною Україною: Угорщина на Закарпатську область, Польща - Львівську, Тернопільську, Ровенську та Івано-Франківську області, Румунія - Північну Буковину, Південну Бессарабію.

Зазначимо що, головною тенденцією розвитку геополітичної ситуації в світі залишається процес формування нової багатополярної системи міжнародних відносин. Водночас відбувається подальша глобалізація всіх сфер життєдіяльності людства.

За таких обставин принципово важливо для України, що США, НАТО, i СС залишаються на своїх позиціях, дотримуючись політики стратегічного стримування Російської Федерації, послідовно нарощуючи проти неї санкції, посилюючи підтримку України та зміцнюючи безпеку Свропи зі Східного напрямку. Провідні західні країни та міжнародні організації фактично ухвалили принципові рішення щодо своєї відповідальності за Україну, за іiі подальшу інтеграцію в ЄС та НАТО в тій чи іншій формі.

У подалыших дослідженнях $\epsilon$ необхідність проаналізувати завдання, принципи та форми бойового застосування ЗС РФ за досвідом стратегічних командноштабних навчань серії “Захід”, “Кавказ”, “Центр”, “Схід”, як головних елементів воєнно-політичної діяльності Росії у військово-політичній сфері та підсумковими етапами бойової підготовки іiї збройних сил одного 3 основних інструментів РФ 3 реалізації іiі зовнішньої, а за певних обставин, i внутрішньої політики.

\section{СПИСОК ВИКОРИСТАНОЇ ЛІТЕРАТУРИ}

1. Воєнна доктрина Росії. 2014. URL: https://militaryarms.ru (дата звернення: 20.02.2020).

2. Стратегія національної безпеки РФ. 2015. URL: https://rg.ru>nac-bezopasnost-sate-doc (дата звернення: 20.02.2020).

3. Завдання бойового застосування Збройних Сил Росії на основних стратегічних (операційних) напрямках. URL: https:// www.bintel.com.ua (дата звернення: 18.02.2020).

4. Січень I. Організована злочинність як інструмент "гібридних" війн Росії. Бінтел (журнал геополітичної аналітики). 2018. № 2 (10). С. 20-29.

5. Гвоздь В. Особливості розвитку ситуації у світі в 2017 році в контексті національних інтересів України. Бінтел (журнал геополітичної аналітики). 2017. № 4 (8). С. 18-27.

6. Січень І. Розвиток ситуації довкола України та у світі на найближчу i середньострокову перспективу. Бінтел (журнал геополітичної аналітики). 2017. № 4 (8). С. 28-36.

7. Гвоздь В. Україна і світ: геополітичні підсумки 2019 року. Бінтел (журнал геополітичної аналітики). 2019. № 4. С. 4-37.

8. Ивженко Т. Территориальные претензии к Украине: аппетиты Румынии растут. URL: http://vlasti.net/news/96314 (дата звернення: 18.02.2020).

9. LIVEJOURNAL. URL: http://blackseafleet21.com/news/9-03-2014_mechty-ot-sana-do-donakakie-strany-imejut-territorialnye-pretenzii-kukraine-i-na-kakie-z (дата звернення: 18.02.2020).

10. "Польша заберёт Западную Украину, а Киев с этим согласится". URL: https://www.gumilevcenter.ru/polsha-zaberjot-zapadnuyu-ukrainu-a-kievs-ehtim-soglasitsya/ (дата звернення: 18.02.2020).

11. В Польше заявили, что без западной Украины и западной Беларуси их страна "неполноценное государство”. URL: http://antifashist.com/item/vpolshe-zayavili-chto-bez-zapadnoj-ukrainy-izapadnoj-belarusi-ih-strana-nepolnocennoegosudarstvo.html (дата звернення: 20.02.2020).

12. "Наибольшая опасность для Украины исходит от Венгрии”. URL: https://fakty.ua/308193-netolko-rossiya-mogut-li-vengriya-i-rumyniya- 
prisoedinitsya-k-anneksii-ukrainskih-zemel (дата звернення: 22.02.2020).

Стаття надійшла до редакційної колегії 06.04.2020

\section{Short-term and medium-term threats to the national security in the military sphere of Ukraine}

\section{Annotation}

The article considers the main factor influencing the development of the situation around Ukraine and is the main threat to its national security in the military sphere remains armed aggression of the Russian Federation, which, despite some decrease in the intensity of the fighting in the Donbass, prepared for a military invasion of Ukraine, including in the form of a full-scale offensive. Of the Russian Federation in the framework of the "hybrid" war against Ukraine intensified the practice of political terrorism, which is evidence of its failure to destabilize the situation in the Ukrainian territory the organization of mass social unrest.

Another factor is the governments of the countries bordering Ukraine, under the influence of the local media and the pressure of political, radical parties put forward territorial claims on the territory, "unfairly" lost in the XIX and XX centuries, which are now Western Ukraine: Hungary (Transcarpathian region), Poland (Lviv, Ternopil, Rivne and Ivano-Frankivsk region), Romania (Northern Bukovina, Southern Bessarabia).

Note that the main tendency of development of the geopolitical situation in the world is the process of formation of a new multipolar system of international relations. At the same time, growing globalization of all spheres of human activity.

Intensification of contradictions between the USA, NATO, EU and the Russian Federation with the Ukrainian and other issues exacerbated the confrontation of the parties in fact to the level of the cold war. Given this, the most dangerous trend is the increasing military activity of the United States, NATO and Russia as at the strategic level in the nuclear missile sphere and the main directions of their direct clashes in the black sea region.

In such circumstances it is fundamentally important for Ukraine that the US, NATO and the EU remain in their positions, adhering to a policy of strategic deterrence of the Russian Federation, consistently increasing sanctions against it, reinforcing the support of Kyiv and strengthening the security of Europe from the East. The leading Western countries and international organizations have actually taken a fundamental decision regarding its responsibility for Ukraine, for its further integration into the EU and NATO in one form or another.

This also shows that the Russian Federation tries in vain to change the policy of the US and Europe on Russian and Ukrainian destinations, to undermine the unity of the EU and NATO methods of conducting hybrid war, including influencing the election results in Western countries.

Keywords: "hybrid" war; threats; situation; forecast; security. 